\title{
PLOT SIZE AND SHAPE FOR FIELD TRIALS WITH FORAGE CACTUS PEAR
}

\author{
Bruno Vinícius Castro GUIMARÃES ${ }^{1}$ \\ Sérgio Luiz Rodrigues DONATO² \\ Ignacio ASPIAZÚ ${ }^{3}$ \\ Alcinei Mistico AZEVEDO ${ }^{4}$ \\ Abner José de CARVALHO 3
}

- ABSTRACT: This study aimed to determine the size and shape of experimental plots that provide maximum precision using relative information method. This trial was conducted at the Federal Institute of Bahia. Plant height, cladode length, cladode width, cladode thickness, cladode area, cladode area index, number of cladodes, cladode total area and yield were measured in the third production cycle, 930 days after planting. The plants, defined as basic units, were arranged in 39 plot sizes so that the crop would fill the whole experimental area. Then, plot shapes with higher relative information and equal plot size in basic units were selected. The experimental plot with eight basic units in size ensures higher efficiency in the experimental evaluation. This combination between size and shape, besides meeting all evaluation requirements of the characteristics normally assessed in studies with forage cactus pear, has the maximum control of soil heterogeneity, thereby decreasing experimental error and significantly increasing precision.

- KEYWORDS: Basic unit; Opuntia ficus-indica Mill; relative information.

\section{Introduction}

'Gigante' cactus pear (Opuntia ficus-indica Mill) is the most resilient and productive forage crop grown in semiarid regions (MARQUES et al., 2017); however, it has the potential of attaining higher yields by using specific managements (ROCHA et al., 2017). Therefore, several studies have been carried out aimed at better understanding the crop, on

\footnotetext{
${ }^{1}$ Instituto Federal do Amazonas - IFAM, Departamento de Ciências Agrárias, CEP 69.750-000, São Gabriel da Cachoeira, AM, Brazil. E-mail: bvinicius20@yahoo.com.br

${ }^{2}$ Instituto Federal de Educação Ciência e Tecnologia - IFBAIANO, Setor de Agricultura, CEP 46.430-000, Guanambi, BA, Brazil. E-mail: sergio.donato@ifbaiano.edu.br

${ }^{3}$ Universidade Estadual de Montes Claros - UNIMONTES, Departamento de Ciências Agrárias, CEP 39440.00, Janaúba, MG, Brazil. E-mail: ignacio.aspiazu@unimontes.br, abner.carvalho@unimontes.br

${ }^{4}$ Universidade Federal de Minas Gerais - UFMG, Instituto de Ciências Agrárias, CEP 39.404-547, Montes Claros, MG, Brazil. E-mail: alcineimistico@hotmail.com
} 
the use of irrigation techniques, spacing, agricultural inputs, among other agronomic resources (LIMA et al., 2016; DANTAS et al., 2017; DONATO et al. 2017).

The success of field trials demands more precise and planned designs at a minimum cost (CARGNELUTTI FILHO et al., 2018; GUARÇONI et al., 2020). For the implications of treatments in field trials, whether testing cropping practices, fertilizer rates, hormone application, irrigation levels, or other techniques on forage cactus pear (DONATO et al., 2017), experimental precision is essential to improve the reliability of inferences drawn from the findings.

Obtaining significant results consistent with the proposal of the study at a minimum operational cost depends mainly on increasing experimental precision (DONATO et al., 2018). Thus, there are several promising methods for determining the optimum plot size in basic units, such as Modified Maximum Curvature Method - (LESSMAN and ATKINS, 1963), as verified by Guimarães et al. (2019a, 2019b); Comparison of Variances Method (VALLEJO and MENDONZA, 1992), studied by Guimarães et al. (2019b, 2019c); Linear Response Plateau Model and Quadratic Response Plateau Model (PARANAÍBA et al., 2009), presented by Guimarães et al. (2019b) and Hatheway's Convenient Plot Size (HATHEWAY, 1961), corroborated by Guimarães et al. (2020).

However, due to specificities or propositions associated with the methods, determining the optimum plot size is restricted to the number of basic units, with little consideration about the shape or dimension of the experimental plot, even though an adequate plot shape is recommended as an essential foundation for the success in field trials (SOUSA et al., 2016).

Relative information method proposed by Keller (1949) aims to observe the effect of plot shape, based on the ratio between width and length, on experimental precision, so that the coefficients of variation of the different plot shapes having the same number of basic units are tested. Since plot dimensions are influenced by soil heterogeneity, climate conditions and the crop under study (SOUSA et al., 2016), plot shape with the lowest coefficient of variation must be selected.

Due to the need of improving studies on plot size and shape for 'Gigante' cactus pear, this study aimed to determine the plot shape that provides the maximum precision in field trials using the relative information method, as well as the number of basic units per experimental plot.

\section{Material and methods}

\subsection{Experimental characterization: Soil, climate and experimental delimitation}

The experiment was carried out at Baiano Federal Institute, campus Guanambi, state of Bahia, Brazil, located at $14^{\circ} 13^{\prime} 30^{\prime \prime} \mathrm{S}, 42^{\circ} 46^{\prime} 53^{\prime \prime} \mathrm{W}$ and altitude $525 \mathrm{~m}$. The soil on the experimental area is a Litolic Neosol, with flat to undulating relief (EMBRAPA, 2013). The climate of the region is defined as hot, tropical semiarid, according to Köppen climate classification. Mean annual rainfall and temperature are $670.2 \mathrm{~mm}$ and $25.9{ }^{\circ} \mathrm{C}$, respectively.

The experiment was conducted on a homogeneous area. Each plant was considered a basic unit - BU. Plants were subjected to the same cultural practices and spaced at $2.0 \mathrm{~m} \mathrm{x}$ $0.2 \mathrm{~m}$, with eight rows consisting of 48 plants each, totalling $384 \mathrm{BUs}$. 


\subsection{Evaluated agronomic characteristics}

In the third production cycle, 930 days after planting, the following vegetative characteristics were measured: plant height $(\mathrm{PH}-\mathrm{m})$, cladode length $(\mathrm{CL}-\mathrm{cm})$, cladode width $(\mathrm{CW}-\mathrm{cm})$, cladode thickness $(\mathrm{CT}-\mathrm{mm})$, cladode area $\left(\mathrm{CA}-\mathrm{cm}^{2}\right)$, cladode area index (CAI - dimensionless), number of cladodes (NC - unit), cladode total area (CTA $\left.\mathrm{cm}^{2}\right)$ and yield $\left(\mathrm{Y}-\mathrm{kg} \mathrm{ha}^{-1}\right)$.

\subsection{Model for estimating relative information}

Plants were arranged simulating 39 plot sizes which would allow plants to fill the whole experimental area. Then, plot shapes with higher relative information and equal plot size (BU) were selected. Relative information method (RI) evaluates the influence of plot shape as to both length and width on experimental precision. Among the 39 plot shapes arranged on the experimental area, 15 plot shapes with the highest relative information were selected (Figure 1). The coefficients of variation and the practical use of their corresponding plot shapes were assessed.

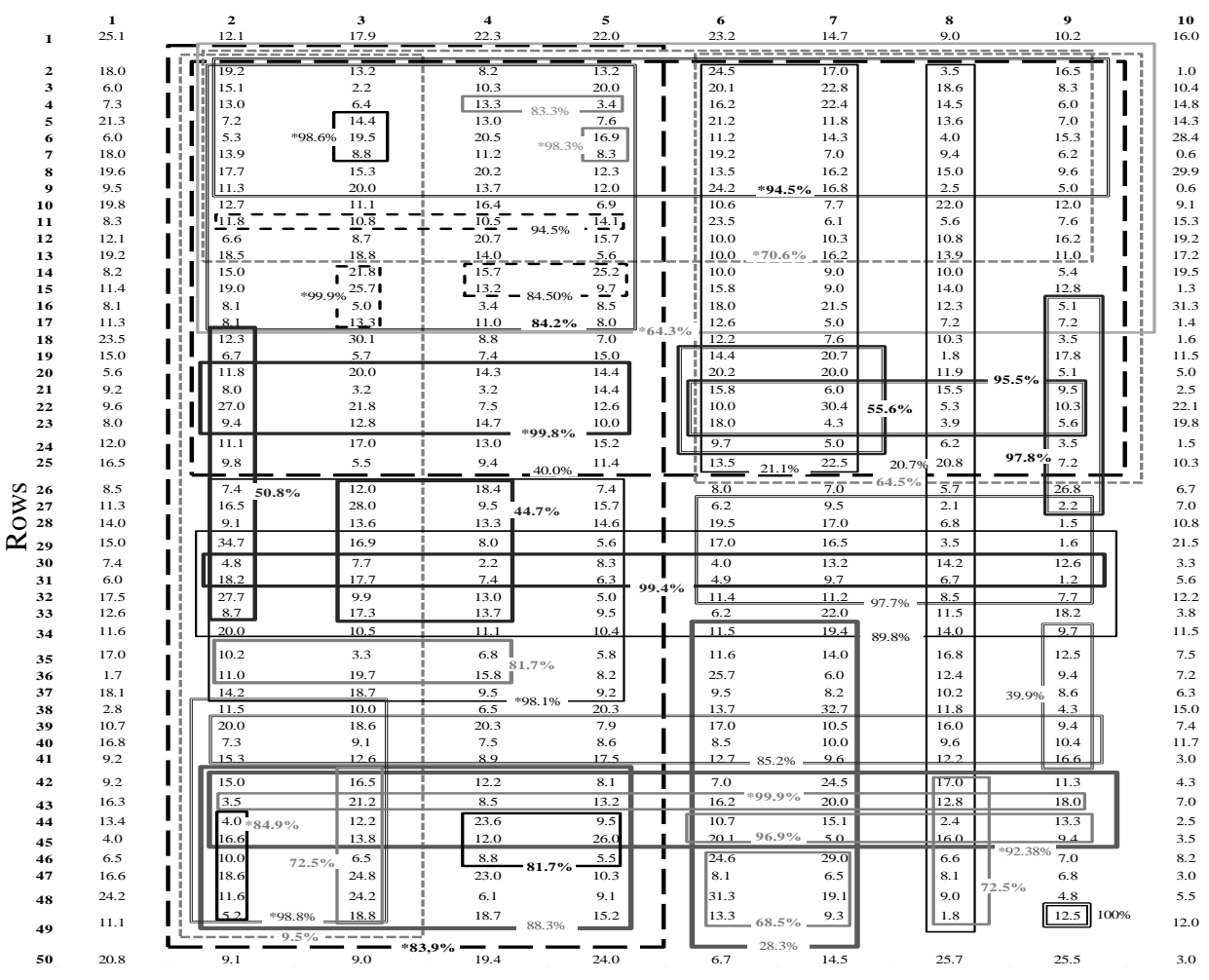

Columns

Figure 1- Scheme of the blank trial using as example the yield of 'Gigante' forage cactus pear, with the 39 plot sizes derived from combining neighboring basic units. $\left(^{*}=\right.$ Selected plot format for possible experimental combinations). 
Using RI method, the between-plot variance of the phenotypic characteristics measured on plots with $X$ BUs in size for each pre-established plot shape was determined:

$$
S_{x}^{2}=\frac{\sum_{i}\left(X_{i}-M(X)\right)^{2}}{N P-1}
$$

where $X_{i}$ is the studied variable of the $i$-th plot,

$$
M(X)=\frac{\sum_{i} X_{i}}{N P}
$$

where $M$ is the mean of the studied variable of plots with $X$ BUs in size and NP is the number of plots with $X$ BUs in size.

The relative information is a percentage measurement determined by the ratio between two variances: the variance on a plot composed by only one $\mathrm{BU}\left(V_{l}\right)$ and the comparable variance $\left(V_{c}\right)$ obtained by dividing the variance by its corresponding plot size in BUs (KELLER, 1949).

$$
R I(\%)=\frac{V_{1}}{V_{c}} \times 100
$$

By means of this equation, the variance of the plot with one BU provides $100 \%$ relative information, so the ratio between this variance and the comparable variance is the percentage of relative information of each plot shape to be selected. With this result, the most suitable plot shapes for assessing phenotypic characteristics in forage cactus pear were selected.

Owing to the specificity of the method a plot with a shape composed by one column and one row (1 C x $1 \mathrm{R})$, i.e. one BU, has the highest relative information for all variables. However, RI is not directly linked to plot size in basic units, but rather to its shape (KELLER, 1949).

Soil heterogeneity indices for assessing phenotypic characteristics associated with the different plot shapes were obtained using two methods: intraclass correlation coefficient (ALVES and SERAPHIN, 2004) and the empirical relationship proposed by Smith (1938) using both a blank and designed trial.

Soil heterogeneity $(\hat{b})$ estimated by the intraclass correlation coefficient method (ALVES and SERAPHIN, 2004) can be defined by the equations:

$$
\begin{aligned}
& \hat{b}=1-\frac{\log [m-(m-1)(1-\hat{p})}{\log m} \\
& \hat{p}=\frac{\sigma_{e}^{2}}{\sigma_{e}^{2}+\sigma_{d}^{2}+\sigma_{c}^{2}+\sigma_{b}^{2}+\sigma_{a}^{2}}
\end{aligned}
$$

where $m$ is the number of units per class, $(p)$ is the intraclass correlation coefficient, a is the number of plants on each row; $b$ is the number of rows on each split plot; $c$ is the number 
of split plots on each plot; $d$ is the number of plots on each block; and $e$ is the number of blocks.

The coefficient b was proposed by Smith (1938) through the linear model: $\log V_{x}=$ $\log V_{l}-b(\log (x))$, where $V_{x}$ is the variance of phenotypic characteristics measured in the crop for 15 selected plot sizes; $V_{l}$ is the between-plot variance with one $\mathrm{BU}$; and $x$ is the plot size.

Soil heterogeneity index (b) classifies the soil variability, defined by indirect measurements of agronomic traits, into three levels: below 0.2 , between 0.2 and 0.7 , and above 0.7 , which correspond, respectively, to the following definitions: low variability, where increasing the number of replicates is more effective than increasing plot size; medium variability, where increasing both number of replicates and plot size should be done in combination; and high variability, where increasing plot size is more effective than increasing the number of replicates. Therefore, the closer the index $b$ is to 1 or 0 , the more heterogeneous or homogeneous the experimental plot is, respectively.

In order to obtain the size and format of the plot for experimental evaluation with cactus pear, a joint analysis was established in percentage between the variation coefficient and the relative information of each selected plot size. Thus, by analyzing the graphic comparison between the aforementioned parameters, a line of connection between the points of higher and lower inflection associated with relative information and the coefficient of variation was considered, respectively.

For determining plot shapes using the relative information method, simulation routines were made on Excel ${ }^{\circledR}$ spreadsheets.

\section{Results and discussion}

\subsection{Selection of plot formats by relative information}

Among the 39 plot shapes distributed systematically on the experimental area (Table 1), 15 were selected with the highest relative information among the analyzed plot dimensions.

The different rectangular shaped plots such as $4 \mathrm{C}$ x $48 \mathrm{R}$ and $8 \mathrm{C}$ x $24 \mathrm{R}$ have the same size in terms of basic units, 192 BUs, and yet relative information diverges, with $83.92 \%$ for the former and $40.02 \%$ for the latter, for yield (Table 1). This comparison between shapes allows inferring that a plot with higher RI controls more efficiently the variability in field trials and should be recommended due to the smaller experimental error, and hence, higher precision. For all combinations between columns and rows where it is possible for the crop to fill the whole experimental area, the most suitable shape was determined by the analysis or comparison of RI (KELLER, 1949).

Most plot sizes have different shape options by combining the number of columns and rows (Table 1). Conversely, the increase in plot size (BU), regardless of its shape, tends to have lower relative information values (Table 1). This was expected since by this method, a plot with only one BU has $100 \%$ relative information (KELLER, 1949).

The comparison of variability indices, coefficient of variation and comparable variance, to the relative information using experimental plots of equal size reveals the influence of plot shape on experimental precision (SOUSA et al., 2016). Nonetheless, 
relative information has a greater effect on the selection of large plots, while for a reduced plot size, plot shape has less control of the experimental error (OLIVEIRA et al., 2011).

Although relative information also uses the comparable variance in defining the best plot shape, this method is more commonly used for being more practical as it indicates, in terms of percentage, the most appropriate plot shape (Table 1).

Table 1 - Plot dimensions (PD - $\mathrm{C}=$ number of columns and $\mathrm{R}=$ number of rows), number of basic units (BU), number of plots (NP) and relative information RI(\%) with the various plot shapes for the variables: yield $(\mathrm{Y})$, plant height $(\mathrm{PH})$, total cladode area (TCA), number of cladodes (NC), cladode area index (CAI), cladode area (CA), cladode length (CL), cladode thickness (CT) and cladode width (CW) for the experimental evaluation of 'Gigante' cactus pear

\begin{tabular}{|c|c|c|c|c|c|c|c|c|c|c|c|c|}
\hline \multirow{2}{*}{$\underset{(C \times R)}{P D} B$} & \multirow{2}{*}{$\mathbf{N P}$} & \multirow{2}{*}{$\begin{array}{c}\text { Area } \\
\left(\mathbf{m}^{2}\right)\end{array}$} & \multicolumn{9}{|c|}{ Relative information RI (\%) } & \multirow{2}{*}{$\mathbf{C}$} \\
\hline & & & $\mathbf{Y}$ & PH & TCA & NC & CAI & $\mathbf{C A}$ & $\mathbf{C L}$ & CT & CW & \\
\hline 8192 & 2 & 0 & 0202 & 7 & 44.87 & 34.35 & 48.07 & 28.72 & 15.13 & 4.12 & 7280 & $\mathrm{~S}$ \\
\hline $8 \times 24192$ & 2 & 76.80 & 40.02 & 10.37 & 45.74 & 33.96 & 45.74 & 28.22 & 13.34 & 3.60 & 63.57 & NS \\
\hline $8 \times 16128$ & 3 & 51.20 & 64.52 & 17.75 & 47.01 & 39.77 & 47.01 & 93.90 & 49.97 & 4.96 & 75.23 & S \\
\hline $2 \times 4896$ & 4 & 38.40 & 9.52 & 16.65 & 14.08 & 7.39 & 14.08 & 15.30 & 20.01 & 3.81 & 13.03 & NS \\
\hline $4 \times 2496$ & 4 & 38.40 & 64.49 & 23.91 & 45.73 & 26.37 & 45.73 & 65.15 & 41.65 & 5.10 & 78.26 & NS \\
\hline $8 \times 1296$ & 4 & 38.40 & 70.60 & 28.08 & 77.50 & 54.78 & 77.50 & 94.76 & 54.40 & 8.67 & 97.26 & S \\
\hline $4 \times 1664$ & 6 & 25.60 & 84.23 & 34.23 & 55.07 & 35.71 & 55.07 & 74.51 & 42.14 & 7.11 & 75.94 & NS \\
\hline $8 \times 8 \quad 64$ & 6 & 25.60 & 94.48 & 40.35 & 99.10 & 94.46 & 95.72 & 80.54 & 89.00 & 11.99 & 97.68 & S \\
\hline $1 \times 4848$ & 8 & 19.20 & 20.66 & 22.56 & 27.48 & 16.18 & 27.48 & 26.36 & 26.48 & 7.28 & 20.84 & $\mathrm{NS}$ \\
\hline $2 \times 2448$ & 8 & 0 & 21.07 & 19.48 & 25.70 & 14.67 & 25.70 & 26.50 & 26.69 & 5.96 & 24.76 & NS \\
\hline $8 \times 648$ & 8 & 19.20 & 89.76 & 58.96 & 96.53 & 34.34 & 59.40 & 89.79 & 84.05 & 14.64 & 84.27 & NS \\
\hline $4 \times 1248$ & 8 & 19.20 & 98.05 & 59.41 & 78.22 & 47.03 & 78.22 & 99.44 & 86.96 & 15.89 & 96.17 & S \\
\hline $2 \times 1632$ & 12 & 12.80 & 28.25 & 26.66 & 35.87 & 20.88 & 35.87 & 35.37 & 33.97 & 8.78 & 33.79 & NS \\
\hline $4 \times 8 \quad 32$ & 12 & 12.80 & 88.30 & 52.75 & 95.89 & 66.63 & 95.89 & 98.00 & 74.45 & 14.80 & 84.99 & NS \\
\hline $8 \times 432$ & 12 & 80 & 92.3 & 76.32 & 97.63 & 86.59 & 97.63 & 98.45 & 96.99 & 22.57 & 88.34 & S \\
\hline $4 \times 6 \quad 24$ & 16 & 9.60 & 97.36 & 51.12 & 98.13 & 70.01 & 98.13 & 86.32 & 74.90 & 17.75 & 84.40 & NS \\
\hline $1 \times 824$ & 16 & 9.60 & 39.96 & 29.86 & 42.97 & 27.09 & 42.97 & 33.73 & 32.80 & 9.97 & 30.02 & NS \\
\hline $8 \times 324$ & 16 & 9.60 & 85.24 & 91.75 & 84.34 & 68.79 & 97.31 & 83.13 & 92.80 & 29.68 & 94.61 & NS \\
\hline $2 \times 1224$ & 16 & 0 & 0880 & 99.90 & 88. & 79.61 & 9 & 4 & 59 & 35.12 & 99.54 & S \\
\hline $1 \times 1616$ & 24 & 6.40 & 50.79 & 39.18 & 59.38 & 38.83 & 59.38 & 50.35 & 43.97 & 14.01 & 47.11 & $\mathrm{NS}$ \\
\hline $2 \times 8 \quad 16$ & 24 & 6.40 & 44.73 & 44.01 & 63.13 & 38.52 & 63.13 & 58.89 & 56.25 & 16.28 & 54.65 & NS \\
\hline $4 \times 416$ & 24 & 6.40 & 99.76 & 92.24 & 93.53 & 74.36 & 93.53 & 96.85 & 81.29 & 53.40 & 98.27 & 5 \\
\hline $8 \times 216$ & 24 & 6.40 & 99.34 & 91.14 & 89.68 & 73.92 & 89.68 & 94.25 & 77.27 & 42.62 & 95.46 & NS \\
\hline
\end{tabular}


Criterion (C), non-selected (NS) and selected (S) plot shape.

Table 1 - (Continuation) - Plot dimensions (PD - C = number of columns and $\mathrm{R}=$ number of rows), number of basic units (BU), number of plots (NP) and relative information $\mathrm{RI}(\%)$ with the various plot shapes for the variables: yield (Y), plant height (PH), total cladode area (TCA), number of cladodes (NC), cladode area index (CAI), cladode area (CA), cladode length (CL), cladode thickness (CT) and cladode width (CW) for the experimental evaluation of 'Gigante' cactus pear

\begin{tabular}{|c|c|c|c|c|c|c|c|c|c|c|c|c|c|}
\hline \multirow{2}{*}{$\begin{array}{c}\text { PD } \\
(\mathbf{C} \times \mathbf{R})\end{array}$} & \multirow{2}{*}{$\mathbf{B U}$} & & \multirow{2}{*}{$\begin{array}{c}\text { Area } \\
\left(\mathbf{m}^{2}\right)\end{array}$} & \multicolumn{9}{|c|}{ Relative information RI (\%) } & \multirow{2}{*}{$\mathbf{C}$} \\
\hline & & & & $\mathbf{Y}$ & PH & 1 & $C$ & AI & A & $\mathbf{C L}$ & CT & CW & \\
\hline $2 \times 6$ & 12 & 32 & 4.80 & 55.64 & 48.57 & 68.17 & 43.87 & 68.17 & 61.93 & 61.17 & 20.36 & 58.09 & NS \\
\hline 3 & 12 & 2 & 80 & .47 & .31 & 2.40 & 34 & .40 & .73 & 88.67 & 2 & 6.03 & S \\
\hline x 12 & 12 & 32 & . & 97.83 & 89.25 & 91.50 & 99.82 & 91.50 & & 93.87 & 36.19 & & $\mathrm{~S}$ \\
\hline $1 \times 8$ & 8 & 48 & 3.20 & 72.47 & 59.67 & 92.15 & 62.51 & 92.15 & 74.34 & 68.73 & 24.49 & 68.17 & NS \\
\hline $2 \times 4$ & 8 & 48 & 3.20 & 68.53 & 63.71 & 76.83 & 54.56 & 76.83 & 70.47 & 65.17 & 29.69 & 70.70 & NS \\
\hline $4 \times 2$ & 8 & 48 & 3.20 & 90.81 & 85.52 & 91.11 & 80.02 & 91.71 & 94.03 & 98.85 & 49.01 & 96.42 & NS \\
\hline $8 \times 1$ & 8 & 48 & 200 & 99.94 & 96.84 & 95.55 & 98.44 & 97.94 & 98.51 & 99.80 & 77.24 & 97.36 & S \\
\hline $1 \times 6$ & 6 & 64 & 2.40 & 84.87 & 78.64 & 97.48 & 65.67 & 99.34 & 89.30 & 79.73 & 39.16 & 92.62 & $S$ \\
\hline $2 \times 3$ & 6 & 64 & 2.40 & 81.08 & 72.99 & 89.87 & 70.37 & 97.86 & 87.32 & 78.24 & 38.46 & 85.34 & NS \\
\hline $1 \times 4$ & 4 & 96 & & 99.89 & 96.88 & 94.68 & 99.28 & 99.94 & 99.54 & 98.68 & 93.35 & 90.20 & S \\
\hline $2 \times 2$ & 4 & 96 & 1.60 & .50 & 82.17 & 90.08 & 73.23 & 90.08 & 92 & 85.27 & 52.16 & 94.85 & NS \\
\hline $4 \times 1$ & 4 & 96 & 1.60 & 94.50 & 91.52 & 84.80 & 85.88 & 8 & 98 & 91 & 86.93 & 91 & NS \\
\hline $1 \times 3$ & 3 & 128 & 1.20 & 98.60 & 89.70 & 97.23 & 88.62 & 97.23 & 92.84 & 84.96 & 53.71 & 92.60 & $S$ \\
\hline $1 \times 2$ & 2 & 192 & 0.80 & 98.25 & 99.70 & 96.68 & 94.29 & 96.68 & 98.13 & 99.04 & 97.71 & 95.04 & $S$ \\
\hline $2 \times 1$ & 2 & 192 & 0.80 & 83.27 & 98.66 & 83.14 & 80.19 & 83.14 & 92.45 & 91.77 & 84.54 & 93.51 & NS \\
\hline $1 \times 1$ & 1 & 384 & 0.40 & 100 & 100 & 100 & 100 & 100 & 100 & 100 & 100 & 100 & $S$ \\
\hline
\end{tabular}

Criterion (C), non-selected (NS) and selected (S) plot shape.

Plot shape is selected based on the greater value of the relative information of a given experimental area, which mainly occurs in response to soil heterogeneity. Petersen (1994) adds that plot shape is more important in heterogeneous environments or with high gradient of variability, as observed in this study on forage cactus pear.

\subsection{Soil heterogeneity index}

Values of $b$ estimated by the method of Smith (1938) using data from a blank trial as well as a trial simulating a split plot design, and by the intraclass correlation coefficient developed by Alves and Seraphin (2004) (Figure 2). Soil variability estimates ranged from 
0.402 to 1.419 across characteristics, which means that the soil is heterogeneous or with low correlation between neighbouring basic units (SMITH,1938).

Furthermore, based on Figure 2, coefficient $b$ is highly similar across estimated values for each measured characteristic, with the lowest variation between the methods being 0.03 , $0.04,0.08,0.08$ and 0.13 for plant height, number of cladodes, total cladode area, cladode area index and yield, respectively. However, the variables directly related to cladode size had the highest variation: $0.43,0.27,0.23$ and 0.20 for cladode area, length, width and thickness, respectively.

The high variability in productivity can be seen in Figure 2B. This Figure shows places within the experiment where the plants showed low productivity (Dark blue color) and other places where the plants showed higher productivity (Yellow and orange colors). This variability was irregular, as no distribution gradient was observed in the direction of the rows or columns. The variability in the productivity of forage cactus pear within the experiment can be justified by different factors, such as the soil heterogeneity index (Figure 2A) (SMITH, 1938), organic fertilization and spacing (PADILHA JUNIOR et al., 2016; DONATO et al., 2017; BRITO et al., 2018), irrigation (DANTAS et al., 2017), cultivation systems and harvest management (AMORIM et al., 2017).

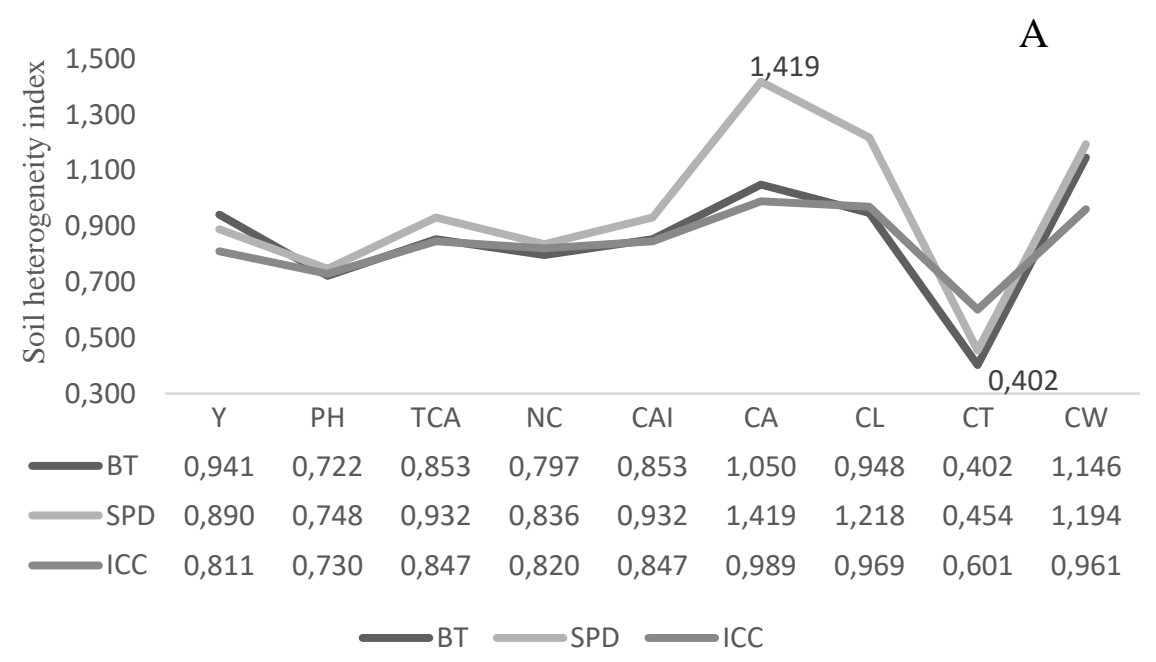

Figure 2A - Values of soil heterogeneity index (b) estimated by the method proposed by Smith (1938) on the basis of a blank trial (BT) and a trial designed as a split plot design (SPD), and by the intraclass correlation coefficient (ICC) (LIN and BINNS, 1984), for the variables: yield (Y), plant height $(\mathrm{PH})$, total cladode area (TCA), number of cladodes (NC), cladode area index (CAI), cladode area (CA), cladode length (CL), cladode thickness (CT) and cladode width $(\mathrm{CW})$ for the experimental evaluation of 'Gigante' cactus pear (A). 


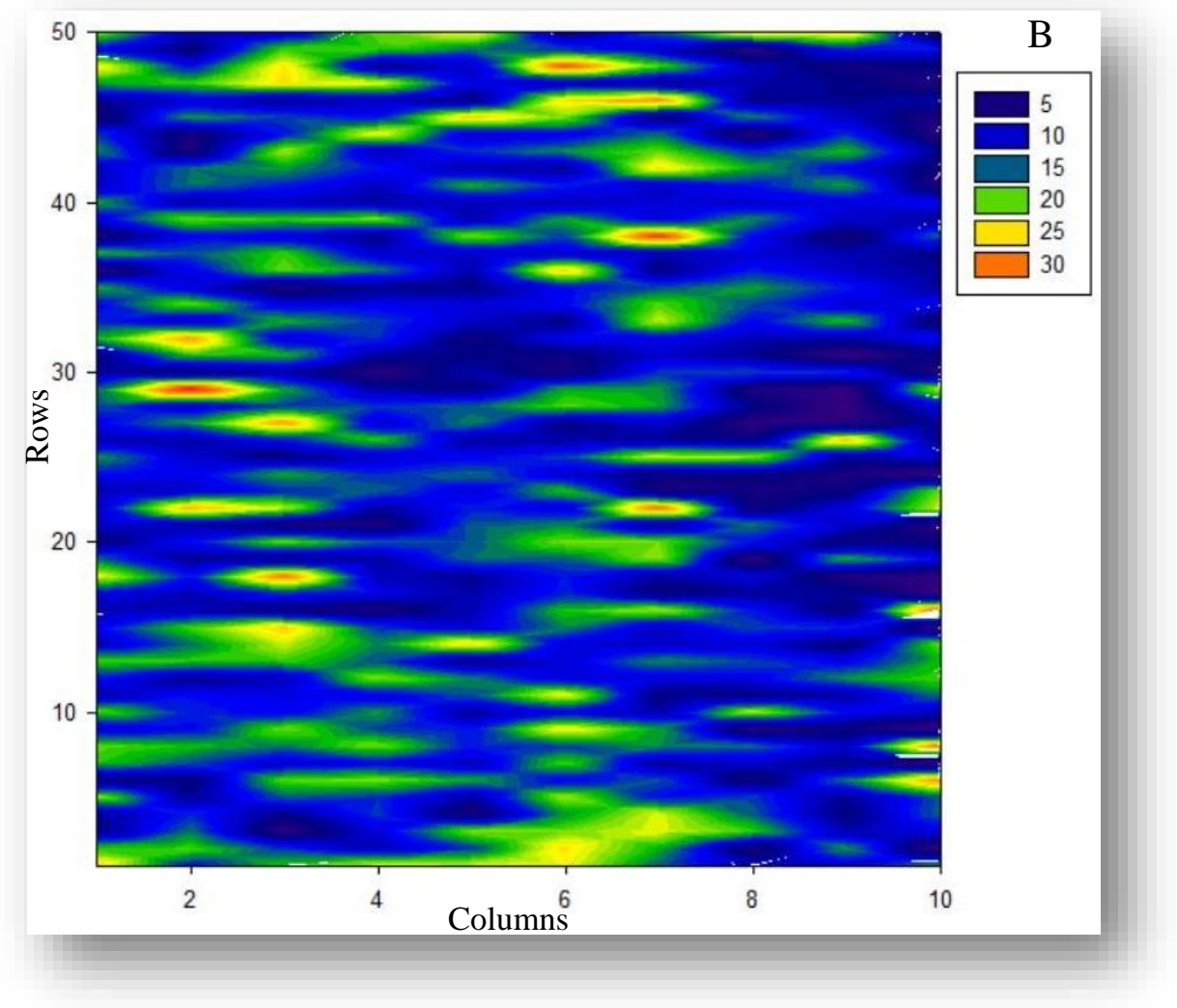

Figure $2 \mathrm{~B}$ - Surface representation of the productivity response $\left(\mathrm{Kg} \mathrm{ha}^{-1}\right)$ obtained in each plant as a function of its positioning within the experimental area, in which the shades in blue and orange/yellow indicate, respectively, low and high productivity (B).

\subsection{Relation between relative information and coefficient of variation}

The analysis of coefficient $b$ on the experimental area shows high between-plot heterogeneity for all characteristics. This suggests that increasing plot size is more effective than increasing the number of replicates. Additionally, the graphical comparison between the coefficient of variation and the relative information may be useful in selecting the most suitable plot size and shape for field trials on forage cactus (Figure 3). 

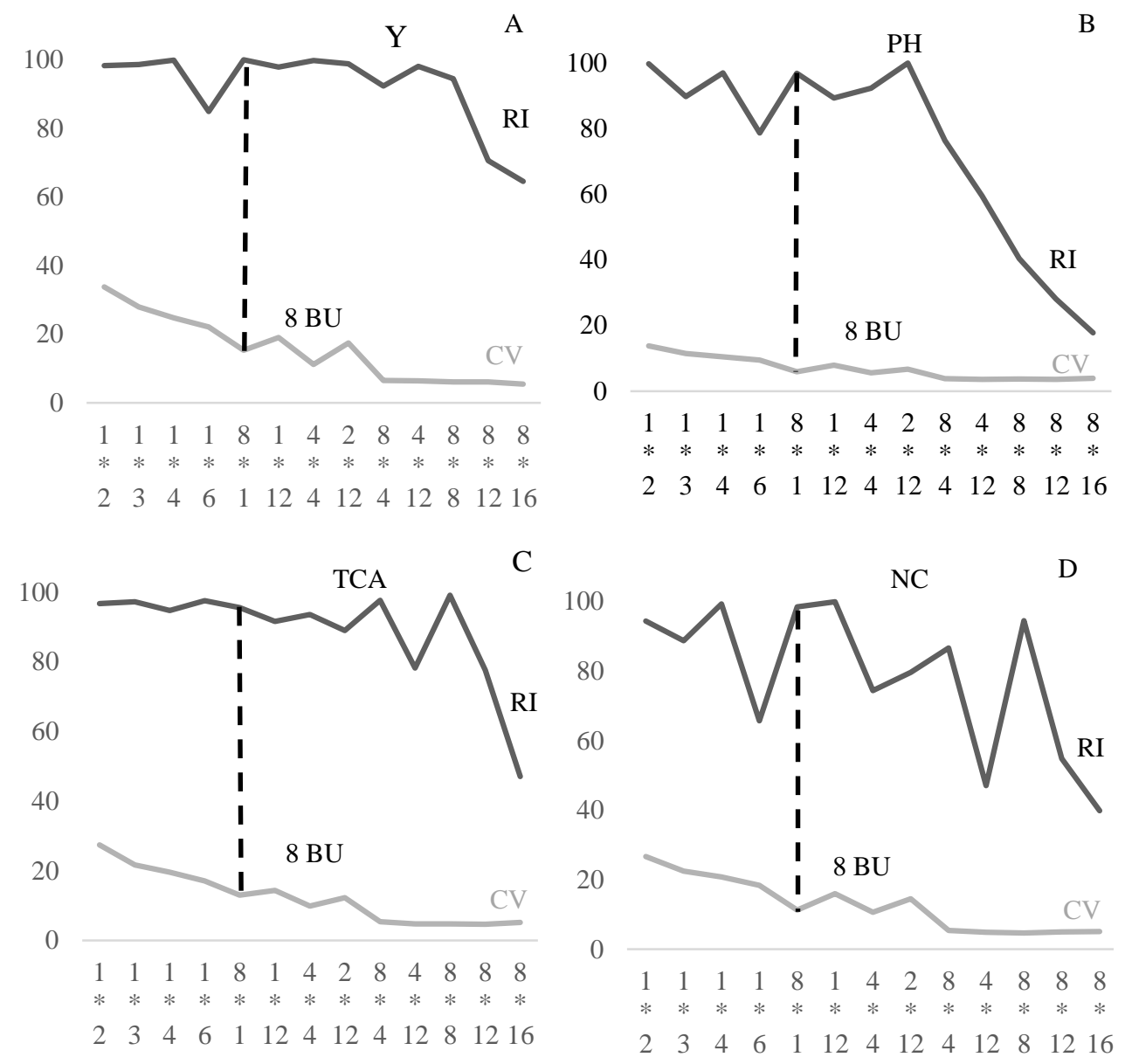

Figure 3 (A-D) - Graphical comparison between the coefficient of variation and relative information for plot sizes and shapes for field trials on forage cactus with the following characteristics: yield - Y (A), plant height - PH (B), total cladode area - (TCA - C), and number of cladodes - NC (D). BU - basic units. 

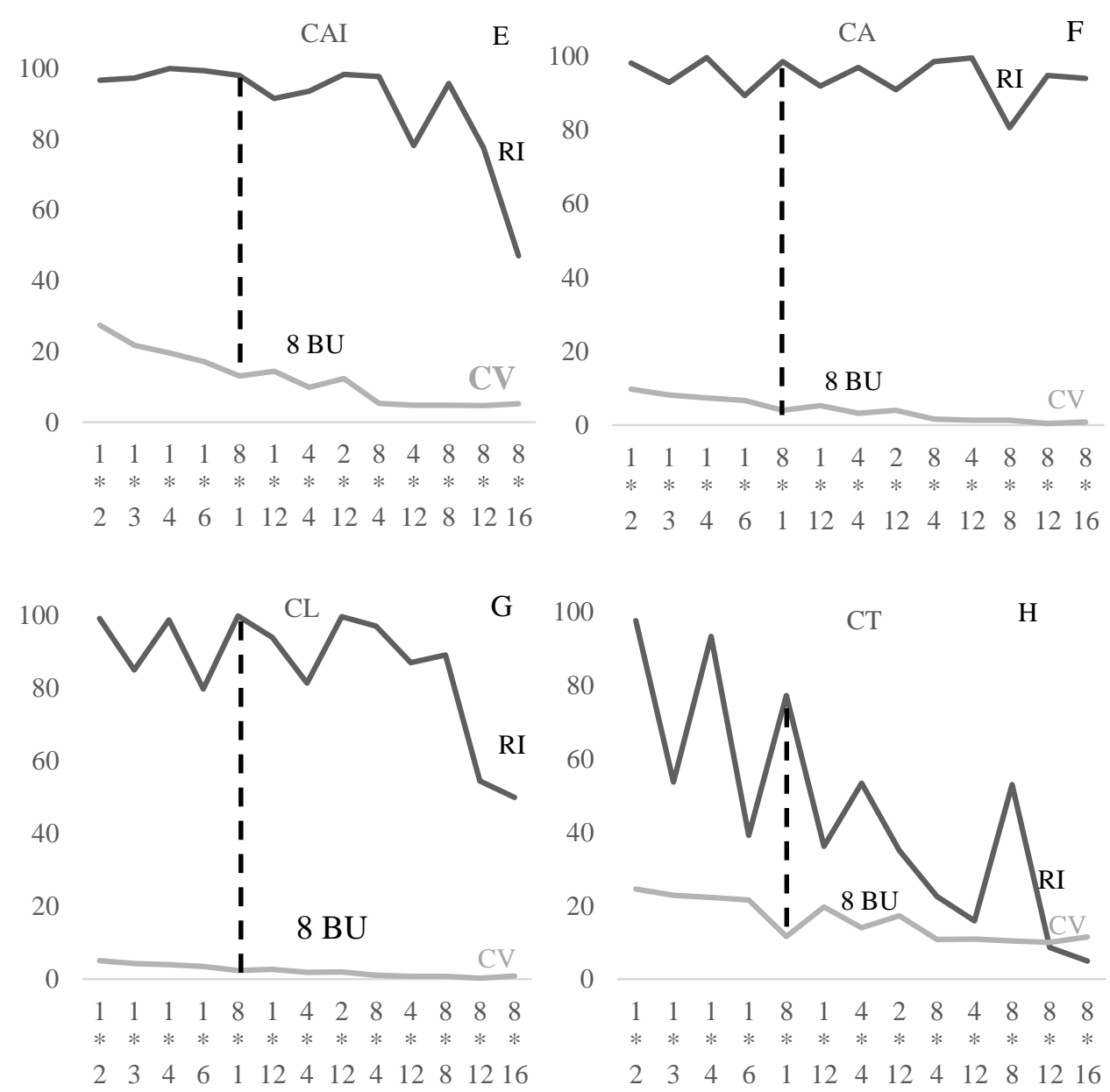

Figure 3 (E-H) - Graphical comparison between the coefficient of variation and relative information for plot sizes and shapes for field trials on forage cactus with the following characteristics: CAI (E), cladode area - CA (F), cladode length - CL (G), and cladode thickness - CT (H). BU - basic units. 


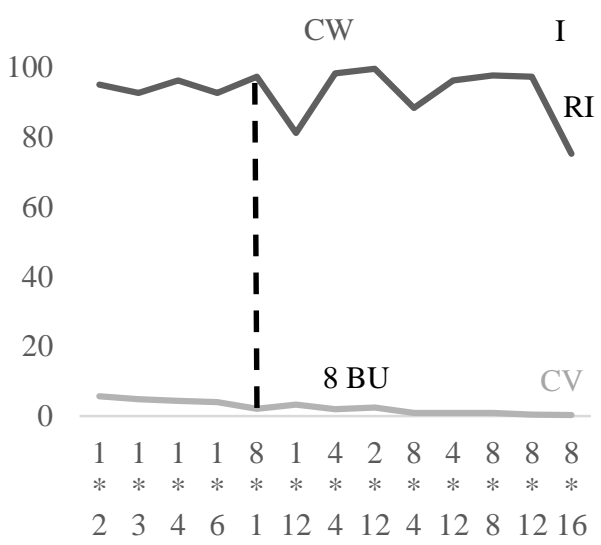

Figure 3 (I) - Graphical comparison between the coefficient of variation and relative information for plot sizes and shapes for field trials on forage cactus with the following characteristics: cladode width - CW. BU - basic units.

Among the 39 sizes and shapes of pre-established plots (Figure 1, Table 1 and Figure 3 ) the experimental arrangements having higher relative information were selected for all measured characteristics (Figure 1). 15 plot sizes and shapes with both higher relative information (RI) and stable coefficient of variation (CV) were evaluated. Based on the association of these two parameters, it was possible to graphically define the optimum plot size and shape for field trials on 'Gigante' forage cactus pear (Figure 3).

In the graphical analysis between the variability indices determined in this study, RI and $\mathrm{CV}$, and plot shapes (C $\times \mathrm{R})$, the optimum plot sizes were consistent with eight BUs and $8 \mathrm{C} \mathrm{x} 1 \mathrm{R}$ shape for all characteristics (Figure 3), representing an area of $3.2 \mathrm{~m}^{2}$. The comparison of $8 \mathrm{C} \times 1 \mathrm{R}$ shape to other experimental plot shapes, such as the combinations $8 \mathrm{C} \mathrm{x} 4 \mathrm{R}, 1 \mathrm{C}$ x $4 \mathrm{R}$ and $1 \mathrm{C} \times 6 \mathrm{R}$, shows that the latter shapes are inferior to the former with respect to the inflection point between the highest RI and the lowest CV (Figure 3).

Thus, a plot size of eight BUs and $8 \mathrm{C} \times 1 \mathrm{R}$ shape ensures higher efficiency in the experimental evaluation since this combination between size and shape has a better control of soil heterogeneity, thereby reducing experimental error and significantly increasing precision. It is worth noting that the size of the experimental plot recommended in this study agree with the findings reported by Guimarães et al. (2019a).

Moreover, higher CV values were associated with plots with only one BU (1 C x $1 \mathrm{R})$, which is understandable seeing that plots of this size are more affected by soil variability (Figure 2). For plot sizes and shapes selected in this study, CV values ranged from 17 to $1.39 \%$ for cladode area index (Figure 3E) and cladode area (Figure 3F), respectively. For these same characteristics, CAI and CA, RI values were 99.34 and $98.51 \%$, respectively. 
These results are highly similar, especially for the CV and RI values, in estimating plots sizes and shapes for sunflower (SOUSA et al., 2016).

Size and shape of experimental plots have been discussed by several papers. Sousa et al. (2016), Donato et al. (2018), Guimarães et al. (2019a, 2019b), Sampaio Filho et al. (2019) and Silva et al. (2019) reported a reduction in CV with increasing plot size. However, after determining the optimum plot size, no significant increase in precision has been reported with increasing plot size (CARGNELLUTI FILHO et al., 2018).

Other studies show that RI decreases in response to the increase in plot size (LÚCIO et al., 2010; SOUSA et al., 2016). Keller (1949) discusses that the ideal plot size is the one from which RI values become stable. Furthermore, according to the creator of the method, the RI of the plot tends to increase as the plot size decreases, which favors the recommendation of plots with values close to one BU. Thus, it can be inferred from the lower CV and the higher RI values that the size of the plot with eight BUs and $8 \mathrm{C} \times 1 \mathrm{R}$ shape provides the best conditions for field trials on 'Gigante' cactus pear.

Studies on 'Gigante' cactus pear have been carried out with several plot sizes measuring 15 (QUEIROZ et al., 2015), 32 (SILVA et al., 2016), 36 (PADILHA JUNIOR et al., 2016) and 32 basic units (BRITO et al., 2018). Nevertheless, based on the findings reported herein, the experimental area can be optimized with a significant reduction in the size and shape of the plot, with further gains in experimental precision by minimizing error and number of sampling units. Thus, plots with eight BUs showed satisfactory results for experimental evaluation with 'Gigante' cactus pear.

\section{Conclusions}

Plot size with eight basic units and rectangular shape $8_{\mathrm{C}} \times 1_{\mathrm{R}}$, representing an area of $3.2 \mathrm{~m}^{2}$, is considered the most suitable experimental plot for evaluating 'Gigante' cactus pear.

\section{Acknowledgements}

Authors would like to thank the Federal Institutes: IFAM and IF-Baiano and to the Montes Claros State University - UNIMONTES. The present study was conducted with the support from the Coordination for the Improvement of Higher Education Personnel - Brazil (CAPES) - Finance Code 001. Also, the authors would like to thank reviewers and editors for their comments and suggestions.

GUIMARÃES, B.V.C.; DONATO, S. L. R.; ASPIAZÚ, I.; AZEVEDO, A. M.; CARVALHO, A. J. Plot size and shape for field trials with forage cactus pear. Rev. Bras. Biom. Lavras, v.39, n.2, p.334349, 2021.

- RESUMO: Este estudo teve como objetivo determinar o tamanho e a forma das parcelas experimentais que fornecem máxima precisão usando o método da informação relativa. O ensaio foi realizado no Instituto Federal Baiano. A altura da planta, o comprimento do cladódio, a largura do cladódio, a espessura do cladódio, a área do cladódio, o índice da área do cladódio, o número de cladódios, a área total do cladódio e o rendimento foram avaliados no terceiro ciclo de produção, 930 dias após o plantio. As plantas, definidas como unidades básicas, foram dispostas em 39 formatos de parcelas, capazes de ocupar toda a área experimental. Em seguida, 
as formas das parcelas foram selecionadas com informações relativas mais altas e tamanhos iguais de parcelas em unidades básicas. $O$ arranjo experimental com oito unidades de tamanho básico assegura maior eficiência na avaliação experimental. Essa combinação de tamanho e forma, além de atender a todos os requisitos para avaliar as características normalmente avaliadas em estudos com a palma forrageira, apresenta controle máximo da heterogeneidade do solo, diminuindo o erro experimental e aumentando significativamente a precisão.

- PALAVRAS-CHAVE: Unidades básicas; Opuntia ficus-indica Mill; informação relativa.

\section{References}

ALVES, S. M. F.; SERAPHIN, J. C. Coeficiente de heterogeneidade do solo e tamanho de parcela. Pesquisa Agropecuária Brasileira, v.39, n.2, p.105-111, 2004.

AMORIM, D. M.; SILVA, T. G. F. da; PEREIRA, P. de C.; SOUZA, L. S. B de; MINUZZI, R. B. Phenophases and cutting time of forage cactus under irrigation and cropping systems, Pesquisa Agropecuária Tropical, v.47, n.1, p.62-71, 2017.

BRITO, C. F. B.; DONATO, S. L. R.; ARANTES, A. M.; DONATO, P. E. R.; SILVA, J. A. Photochemical efficiency in cladodes of 'Gigante' cactus pear cultivated under different spacings and organic fertilization. Rev. Bras. Eng. Agríc. Ambient., v.22, n.5, p.338-343, 2018.

CARGNELUTTI FILHO, A.; ARAÚJO, M. M.; GASPARIN, E.; FOLTZ, D. R. B. Dimensionamento amostral para avaliação de altura e diâmetro de plantas de timbaúva. Floresta Ambiental, v.25, n.1, p.1-9, 2018.

DANTAS, S. F. A.; LIMA, G. F. C.; MOTA, E. P. Viabilidade econômica da produção de palma forrageira irrigada e adensada no semiárido Potiguar. Revista iPecege, v.3, n.1, p.5974, 2017.

DONATO, P. E. R.; DONATO, S. L. R.; SILVA, J. A.; PIRES, A. J. V.; SILVA JUNIOR, A. A. E. Extraction/exportation of macronutrients by cladodes of 'Gigante' cactus pear under different spacing and organic fertilizer. Revista Brasileira de Engenharia Agrícola e Ambiental, v.21, n.4, p.238-243, 2017.

DONATO, S. L. R.; SILVA, J. A.; GUIMARÃES, B. V. C.; SILVA, S. O. Experimental planning for the evaluation of phenotipic descriptors in banana. Revista Brasileira de Fruticultura, v.40, n.5 p.1-13, 2018.

EMBRAPA - Empresa Brasileira de Pesquisa Agropecuária. Sistema brasileiro de classificação de solos. 3.ed. Brasília: Embrapa Informação Tecnológica, 2013. 353p.

GUARÇONI, R. C., ALIXANDRE, F. T.; SOUSA, D. G.; PEREIRA, L. L.; BRIOSCHI JUNIOR, D.; SOUSA, L. H. B. P.; FAVARATO, L. F.; MARCATE, J. P. P. Tamanho da parcela para avaliar características agronômicas e sensoriais do café do arábica. Revista Brasileira de Biometria, v.38, n.1, p.57-68, 2020.

GUIMARÃES, B. V. C.; DONATO, S. L. R.; ASPIAZÚ, I.; AZEVEDO, A. M.; CARVALHO, A. J. Size of plots for experiments with cactus pear cv. Gigante. Revista Brasileira de Engenharia Agrícola e Ambiental, v.23, n.5, p.347-351, 2019a. 
GUIMARÃES, B. V. C.; DONATO, S. L. R.; ASPIAZÚ, I.; AZEVEDO, A. M.; CARVALHO, A. J. Methods for Estimating Optimum Plot Size for 'Gigante' Cactus Pear. Journal of Agricultural Science, v.11, n.14, p.205-215, 2019b.

GUIMARÃES, B. V. C.; DONATO, S. L. R.; ASPIAZÚ, I.; AZEVEDO, A. M.; CARVALHO, A. J. Plot Size by the Variance Comparison Method for With 'Gigante' Cactus Pear. Journal of Agricultural Science, v.11, n.18, p.206-212, 2019c.

GUIMARÃES, B. V. C.; DONATO, S. L. R.; ASPIAZÚ, I.; AZEVEDO, A. M.; CARVALHO, A. J. Optimal plot size for experimental trials with Opuntia cactus pear. Acta of Science and Technology, v.42, n.1, p.2-10, 2020.

HATHEWAY, W. H. Convenient plot size. Agronomical Journal, v.53, n.4, p.279-280, 1961.

KELLER, K. R. Uniformity trial on Hops, Humulus lupulus L., for increasing the precision of field experiments. Agronomical Journal, v.41, p.389-392, 1949.

LESSMAN, K. J.; ATKINS, R. E. Optimum plot size and relative efficiency of lattice designs for grain sorghum yield test. Crop Science, v.3, p.477-481, 1963.

LIN, C. S.; BINNS, M. R. Working rules for determining the plot size and numbers of plots per block in field experiments. Journal of Agricultural Science, v.103, p.11-15, 1984.

LIMA, G. F. C.; REGO, M. M. T.; DANTAS, F. D. G.; LÔBO, R. N. B.; SILVA, J. G. M.; AGUIAR, E. M. Morphological characteristics and forage productivity of irrigated cactus pear under different cutting intensities. Revista Caatinga, v.29, n.2, p.481-488, 2016.

LÚCIO, A. C.; CARPES, R. H.; STORCK, L.; ZANARDO, B.; TOEBE, M.; PUHL, O. J.; SANTOS, J. R. A. Agrupamento de colheitas de tomate e estimativas do tamanho de parcela em cultivo protegido. Horticultura Brasileira, v.28, n.2, p.190-196, 2010.

MARQUES, O. F. C.; GOMES, L. S. P.; MOURTHÉ, M. H. F.; BRAZ, T. G. S.; PIRES NETO, O. S. Palma forrageira: cultivo e utilização na alimentação de bovinos. Caderno de Ciências Agrárias, v.9, n.1, p.75-93, 2017.

OLIVEIRA, G. M. V.; MELLO, J. M.; LIMA, R. R.; SCOLFORO, J. R. S.; OLIVEIRA, A. D. Tamanho e forma de parcelas experimentais para Eremanthus erythropappus. Cerne, v.17, n.3, p.327-338, 2011.

PADILHA JUNIOR, M. C.; DONATO, S. L. R.; SILVA, J. A. S.; DONATO, P. E. R.; SOUZA, E. S. S. Características morfométricas e rendimento da palma forrageira 'Gigante' sob diferentes adubações e configurações de plantio. Revista Verde Agroecologia e Desenvolvimento Sustentável, v.11, n.1, p.67-72, 2016.

PARANAÍBA, P. F.; FERREIRA, D. F.; MORAIS, A. R. Tamanho ótimo de parcelas experimentais: Proposição de métodos de estimação. Revista Brasileira de Biometria, v.27, n.2, p.255-268, 2009.

PETERSEN, R. G. Agricultural field experiments: Design and analysis. New York: Marcel Dekker, Inc., 1994. 409 p.

QUEIROZ, M. G.; SILVA, T. G. F.; ZOLNIER, S.; SILVA, S. M. S.; LIMA, L. R.; ALVES J. O. Características morfofisiológicas e produtividade da palma forrageira em diferentes lâminas de irrigação. Revista Brasileira de Engenharia Agrícola e Ambiental, v.19, n.10, p.931-938, 2015. 
ROCHA, R. S.; VOLTOLini, T. V. GAVA, C. A. T. Características produtivas e estruturais de genótipos de palma forrageira irrigada em diferentes intervalos de corte. Archivos de Zootecnia, v.66, n.255, p.365-373, 2017.

SAMPAIO FILHO, O. M.; SILVA, S. O.; DONATO, S. L. R.; SILVA, A. S.; SILVA, M. S. Optimum experimental plot size in the castor bean. Revista Ciência Agronômica, v.50, n.2, p.276-281, 2019.

SILVA, M. S.; SILVA, S. O.; DONATO S. L. R.; SAMPAIO FILHO, O. M.; SILVA, G. M. A. Optimal size of experimental plots of papaya trees using a modified maximum curvature method. Ciência Rural, v.49, n.9, p.1-7, 2019.

SILVA, J. A.; DONATO, S. L. R.; DONATO, P. E. R.; SOUZA, E. S.; PADILHA JÚNIOR, M. C.; SILVA JUNIOR, A. A. Extraction/export of nutrients in Opuntia ficusindica under different spacings and chemical fertilizers. Revista Brasileira de Engenharia Agrícola e Ambiental, v.20, n.3, p.236-242, 2016.

SMITH, H. F. C. Journal of Agricultural Science, v.28, n.1, p.1-23, 1938.

SOUSA, R. P.; SILVA P. S. L.; ASSIS. J. P. Tamanho e forma de parcelas para experimentos com girassol. Revista Ciência Agronômica, v.47, n.4, p.683-690, 2016.

VALLEJO, R. L.; MENDOZA H. A. Plot technique studies on sweet potato yield trials. Journal of the American Society for Horticultural Science, v.117, n.3, p.508-511, 1992.

Received on 28.04.2020

Approved after revised on 15.07.2020 